\title{
Total Knee Replacement
}

National Cancer Institute

\section{Source}

National Cancer Institute. Total Knee Replacement. NCI Thesaurus. Code C51565.

Surgical replacement of all parts of a damaged knee joint with an artificial joint. 